\title{
ТЕХНОЛОГИЯ ПОЛУЧЕНИЯ БЕЗВИРУСНОГО ПОСАДОЧНОГО МАТЕРИАЛА КАРТОФЕЛЯ СВОБОДНОГО ОТ Х И Ү ВИРУСОВ
}

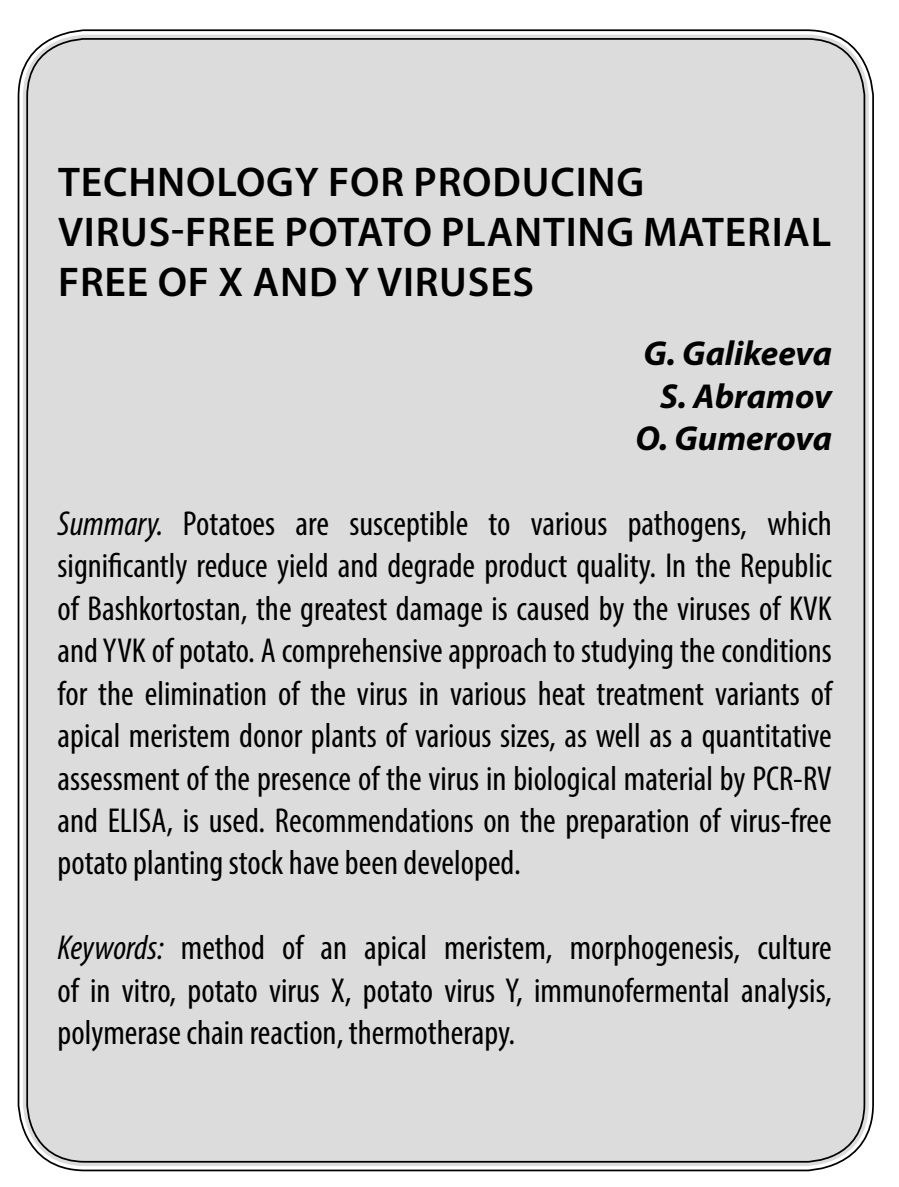

\section{Введение}

$\mathbf{P}$ азработка наиболее эффективных методов оздоровления посадочного материала картофеля является, на сегодняшний день, наиболее актуальным направлением биотехнологии и генетики, так как картофель является одной из наиболее востребованных продовольственных культур в России. Однако часто наблюдается низкий выход урожая [1] из-за повреждения посадочного материала всевозможными вирусными, бактериальными и грибковыми инфекциями. Инфекции передаются контактно через ранки, могут передаваться почвообразующими грибами и насекомыми с грызущим ротовым аппаратом.

\section{Метолы, используемые в работе}

Метод культуры апикальных меристем, заключающийся в вычленении различных размеров меристем из почек картофеля. Данный метод использовали в от-
Галикеева Гузель Фанилевна

К.б.н., дочент, Башкирский Государственный

Педагогический университет им. М. Акмуллы (г. Уфа) galikeevagf@yandex.ru

Абрамов Сергей Николаевич

К.б.н., доцент, Башкирский Государственный Педагогический университет им. М. Акмуллы (г. Уфа) abramov-67@mail.ru

Гумерова Оксана Владимировна

К.б.н., дочент, Башкирский Государственный Педагогический университет им. М. Акмуллы (г. Уфа) gumerova_80@mail.ru

Аннотация. Картофель подвержен действию различных патогенов, которые значительно снижают урожайность и ухудшают качество продукции. В Республике Башкортостан максимальный ущерб наносят вирусы ХВК и ҮВК картофеля. В работе применен комплексный подход к изучению условий элиминации вируса при различных вариантах термообработки растений-доноров верхушечной меристемы различного размера, а также количественная оценка наличия вируса в биологическом материале методом ПЦР-РВ и ИФА. Разработаны рекомендации по получению безвирусного посадочного материала картофеля.

Ключевые слова: метод апикальной меристемы, морфогенез, культура in vitro, X вирус картофеля, Y вирус картофеля, иммуноферментный анализ, полимеразная цепная реакция, термотерапия.

дельности и в сочетании с термотерапией различной продолжительности. Проверку полученного материала на безвирусность проводили методами иммуноферментного анализа (ИФА) и полимеразной цепной реакции в реальном времени (ПЦР-РВ).

\section{Результаты}

Для получения потенциально безвирусного материала в работе применен метод апикальной меристемы. Источником апикальных меристем для получения безвирусных растений-регенерантов послужили клубни картофеля средней величины, без явных внешних и внутренних поражений. В дальнейшем растения-регенеранты были проверены с помощью высокоточного метода ПЦР-РВ и ИФА.

Стерилизацию материала проводили в два этапа:

1. $0,5 \%$ перекисью водорода в течение 5 минут;

2. $70 \%$ этанолом в течение 3 минут. 
В стерильных условиях ламинарного бокса с верхушки ростка удаляли покровные листки, последовательно обнажая боковые и верхушечные меристемы с примордиями. Из пазушных или верхушечных почек вычленяли апикальные меристемы размером 0,1-0,2 мм $^{3}, 0,3-0,4 \mathrm{~mm}^{3}, 0,5-0,6 \mathrm{~mm}^{3}$.

В работе использовали питательную среду МС по прописи Т. Мурасиге и Ф. Скуга (Murasige, Skoog, 1962) с различной концентрацией гормонов ИУК и 6-БАП для индукции каллусогенеза и органогенеза

При культивации эксплантов, полученных из меристем с минимальным размером $\left(0,1-0,2\right.$ мм $\left.^{3}\right)$ без термообработки образовалось 80\% морфогенных каллусов, 20\% каллусов оказались неморфогенными, т.е. на среде для регенерации данные каллусы некротировали.

При увеличении сроков термообработки наблюдалось постепенное снижение выхода морфогенных каллусов и увеличение количества неморфогенных каллусов. Органогенез при различных сроках термообработки при минимальном размере меристемы не наблюдался.

При 8 неделях термообработки экспланты не развивались.

При культивировании in vitro [3] меристем среднего размера были отмечены случаи формирования морфогенных каллусов (имеющих сходные морфологические характеристики с морфогенными каллусами, полученными из меристем минимального размера) и геммогенеза на соответствующих вариантах индукционных сред. Формирования неморфогенного каллуса и индукции гемморизогенеза не наблюдалось.

В обоих случаях индуцированного морфогенеза in vitro максимальная частота индукции наблюдалась при отсутствии термообработки. Эти показатели постепенно снижались при увеличении длительности термообработки от 2 до 6 недель.

При термообработке 8 недель индукция морфогенеза in vitro не наблюдалось, инокулированные экспланты некротировали.

При культивировании in vitro меристем максимального размера были отмечены случаи формирования морфогенных каллусов (имеющих сходные морфологические характеристики с морфогенными каллусами, полученными из меристем минимального и среднего размера) и гемморизогенеза на соответствующих вариантах индукционных сред. Максимальная частота индукции обоих типов морфогенеза in vitro также наблюдалась при отсутствии термообработки и постепенно снижалась при увеличении длительности термообработки до 2-6 недель и полностью отсутствовала после 8 недель.
В дальнейшем растительный материал анализировался методами ИФА и ПЦР-РВ.

Помимо растений-регенерантов анализу подвергались растения, выращенные из семян сорта Дева и Фермер. Семена проращивались in vitro в стерильных условиях. Эти образцы рассматривались как отрицательный контроль.

Положительным контролем являлись почки картофеля.

Для идентификации ХВК и ҮВК [4] вирусов картофеля методом ИФА использовали набор компании Dia-M (MoСква). Анализ проводили с помощью метода «двойной сэндвич» [2].

При анализе растений-регенерантов на присутствие ХВК, вирус был обнаружен в образцах с различным размером апикальных меристем и сроком термической обработки

При анализе растений-регенерантов на присутствие YBК, вирус не был идентифицирован в образцах, полученных из апикальных меристем малых и средних размеров без термической обработки, а также в образцах, подвергшихся термообработке в течение 6 недель.

Был проведен анализ на наличие ХВК и ҮВК в семенах, пророщенных в стерильных условиях и в проростках картофеля. В растениях из семян не были обнаружены вирусы обоих типов, а в проростках из клубней детектировались оба типа вирусов.

Для идентификации ХВК и YВК вирусов картофеля методом ПЦР использовали набор реагентов для выделения нуклеиновых кислот ЦитоСорб/CytoSorb производства компании «СИНТОЛ». Для обнаружения РНК вирусов ХВК и ҮВК картофеля методом полимеразной цепной реакции в реальном времени (ПЦР-РВ) использовался набор реагентов производства компании «СИНТОЛ» Кат.№ PV-001. Исследование проводили на амплификаторе CFX96 («BioRad», США).

Анализ растений-регенерантов, полученных из апикальных меристем размером 0,1-0,2 мм, показал в 33\% случаях полное отсутствие вирусов ХВК и ҮВК. В 66\% образцов обнаружен только ХВК. У растений-регенерантов, полученных из апикальных меристем размером 0,3-0,4 мм X вирус картофеля обнаруживается в 100\% случаев. Причем наработка ХВК вируса начинается с 20 цикла амплификации. Анализ растений-регенерантов, полученных из апикальных меристем размером 0,10,2 мм и 0,3-0,4 мм на присутствие вирусаҮ картофеля показал его полное отсутствие в анализируемых образцах. 
Полученные данные свидетельствуют о том, что метод апикальных меристем не позволяет полностью избавиться от вируса ХВК картофеля, но эффективен в отношении вируса YBK.

При анализе образцов культивируемых методом апикальной меристемы и подверженных термообработке, вне зависимости от размера апикальной меристемы и времени тепловой обработки обнаруживаются оба вируса картофеля. Наработка ХВК вируса начинается уже с 15 цикла амплификации, а наработка ҮВК вируса - с 20 цикла амплификации. Следовательно, количество вируса в образцах при анализе было больше, чем в образцах без термообработки.

Данные результаты объясняются тем, что термообработка от двух до шести недель была сильным стрессовым фактором для клеток меристем, что замедляло рост меристем и, как следствие, повышало репродукцию вирусов в связи со значительным проникновением инфекции из ниже лежащих тканей. В результате чего все образцы В значительной мере были поражены ХВК и ҮВК.

\section{Зак^ючение}

Результаты иммуно-ферментного анализа и ПЦР-РВ демонстрируют, что термическая обработка различной продолжительности разного размера апикальных меристем приводит к элиминации ХВК и ҮВК вирусов. Наиболее эффективным методом получения оздоровленного материала является использование апикальных меристем картофеля размером 0,1-0,2 мм, в которых в 33\% случаев можно добиться полного отсутствия вирусной инфекции для дальнейшего культивирования. Установлено, что абсолютно лишены вирусной активности растения, полученные из семян картофеля.

Выявлено, что при длительной термообработке в 6 недель происходит снижение концентрации ХВК и ҮВК вируса. Но в связи с тем, что выход морфогенных структур крайне низкий, использовать такие образцы не целесообразно. Не рекомендуется использовать апикальные меристемы максимального размера, так как данные образцы в значительно мере поражены вирусной инфекцией.

По результатам проведенного исследования разработаны рекомендации по комбинированному методу получения безвирусного посадочного материала картофеля:

- при минимальном размере меристемы использовать путь морфогенеза каллус $\rightarrow$ гемогенез $\rightarrow$ ризогенез,

- при среднем размере меристемы - каллус $\rightarrow$ гемогенез $\rightarrow$ ризогенез или гемогенез $\rightarrow$ ризогенез.

\section{ЛИТЕРАТУРА}

1. Анисимов, Б. В. Защита картофеля от болезней, вредителей и сорняков / Б. В. Анисимов, Г.Л. Белов, Ю. А. Варицев, С. Н. Еланский, Г. К. Журомский, С. К. Завриев, В.Н. Зейрук, В.Г. Иванюк, М. А. Кузнецова, М.П. Пляхневич, К. А. Пшеченков, Е. А. Симаков, Н. П. Склярова, 3. Сташевски, А.И. Усков, И. М. Яшина.—М.: Кар-тофелевод, 2009.- 272 с.

2. Егоров, А. М. Теория и практика иммуноферментного анализа / А. М. Егоров [и др.].—- М.: Высш. школа, 1991.— 288 с.

3. Лебедева Н. В. Ускоренное размножение ранних сортов картофеля в условиях in vitro и его использование в семеноводстве Северо-Запада РФ.- Министерство сельского хозяйства РФ ФГБОУ ВПО «ВЕЛИКОЛУКСКАЯ ГСХА. — 2015. - 37 с.

4. Пиневич А. В. Вирусология [Текст] / Пиневич А. В. Сироткин А. К., Гаврилова 0. В., Потехин А. А.- учебник. СПб.: Изд-во С.-Петерб. ун-та, 2013.,- 432 с.

(c) Галикеева Гузель Фанилевна ( galikeevagf@yandex.ru),

Абрамов Сергей Николаевич ( abramov-67@mail.ru ), Гумерова Оксана Владимировна ( gumerova_80@mail.ru ).

Журнал «Современная наука: актуальные проблемы теории и практики» 